\title{
Photoperiod as a factor for studying fluctuations of seminal traits during breeding and non-breeding seasons
}

\author{
M. M. Pourseif and G. H. Moghaddam* \\ Department of Animal Science, Faculty of Agriculture, University of Tabriz, Tabriz, Iran. \\ Accepted 24 August, 2012
}

\begin{abstract}
The main purpose of this study was to evaluate the influence of photoperiod on the seminal traits of crossbreed wool-producing rams throughout one year period. For the effect of photoperiod (PTP), two periods were considered: Decreasing daylight length (summer and autumn) and the other, increasing daylight length. For this study, 5 Baluchi $\times$ Moghani $(B L \times M G)$ and 5 Arkharmerino $\times$ Moghani $(A M \times$ MG) rams were used. Semen collection started from first of October 2010 to end of September 2011. After a training period of 2 weeks, semen ejaculates were evaluated for volume, total sperm/ejaculate (TSE), concentration (SC), color, wave motion (WM), percentage of progressive motility (PM), percentage of live sperm (LS) and abnormal sperm (SAB), pH, methylene blue reduction time (MBRT) and semen index (SI). Analysis of the year long data showed that semen with the best quality was collected in September to November $(P<0.05)$. Significant seasonal variations of semen traits were observed for all seminal traits except for PM, LS and MBRT. Yet, no statistical differences were found between the crosses $(P>0.05)$. Although, there were significant seasonal changes in seminal traits of the crosses, the fresh semen showed adequate quality to be used for artificial or natural insemination throughout the year. PTP was found to influence semen production in two genetic groups at $38^{\circ} 02^{\prime} \mathrm{N}$, $46^{\circ} 27^{\prime} \mathrm{E}$ and an altitude of $1567 \mathrm{~m}$ above sea level of Iran. However, these effects were not detrimental to the use of rams for breeding purposes throughout the year.
\end{abstract}

Key words: Genetic group, crossbreed ram, photoperiod, seasonal variation, spermatozoa.

\section{INTRODUCTION}

Sheep production is a traditional economic activity that is mostly used for meat and milk production in Iran. One of the most important factors for economical development of sheep industry is lambing throughout the year. Seasonal breeding is a limiting factor in this species. Therefore, it was determined to evaluate the quality of semen in breeding and non-breeding seasons before using artificial insemination (AI) in sheep. Unlike most domestic livestock species, sheep are widely known for their marked seasonality of breeding activity linked to annual cycle of daily photoperiod (PTP) (Rosa and Bryant,

\footnotetext{
*Corresponding author. E-mail: ghmoghaddam@tabrizu.ac.ir.
} Tel: +984113356004. Fax: +984116698260.
2003). The annual cycle of daily PTP has been identified as the major determinant for this phenomenon in sheep (Rosa and Bryant, 2003). Understanding the fertility quality in non-breeding season will be helpful in developing sheep industry. In contrast to ewes and most horse mares, that become anovulatory outside the breeding season, stallions and rams are not azoospermic during the non-breeding season despite a significant reduction in sperm production or quality (Aurich et al., 1996). Also, overall physiological and behavioral sexual variations are also less pronounced in rams than ewe (Rosa and Bryant, 2003). Therefore, yearlong comparative studies comprising breeding and nonbreeding seasons in rams will be useful for understanding their reproductive physiology. As a result of the revolution in assisted reproductive technologies in domestic animals 
Table 1. Climatic data during the experiment (October 2010 until September 2011) at Khalat Poshan Research Center, University of Tabriz.

\begin{tabular}{lccccc}
\hline \multirow{2}{*}{ Month } & \multicolumn{2}{c}{ Air temperature $\left({ }^{\circ} \mathbf{C}\right)$} & \multicolumn{2}{c}{ Relative humidity (\%) } & Average \\
\cline { 2 - 6 } & Minimum & Maximum & Minimum & Maximum & Day length (h) \\
\hline October & 7.6 & 25.1 & 26.9 & 77.5 & 11.3 \\
November & 0.23 & 16.7 & 32.5 & 71.1 & 10.2 \\
December & -4.08 & 12.4 & 34.7 & 67.9 & 9.6 \\
January & -7.93 & 3.65 & 54.26 & 84.06 & 9.9 \\
February & -7.85 & 4.2 & 51.33 & 85.1 & 10.9 \\
March & -2.32 & 8.51 & 48.5 & 81.75 & 12 \\
April & 2.64 & 16.06 & 25.03 & 67 & 13.3 \\
May & 6.83 & 19.45 & 36.16 & 80.93 & 14.3 \\
June & 11.51 & 28.03 & 23 & 78.54 & 14.8 \\
July & 15.75 & 32.61 & 22.8 & 57.87 & 14.6 \\
August & 16.83 & 33.61 & 15.29 & 56.51 & 13.7 \\
September & 12.16 & 28.22 & 16.74 & 74.16 & 12.5 \\
\hline
\end{tabular}

in Iran, a growing interest and necessity demands more information concerning the reproductive physiology of farm animals (Talebi et al., 2009). The breeding season starts in most ovine breeds during summer or early autumn (Chemineau et al., 1992) and its length varies largely among breeds but in general it ends during the winter (Hafez, 1952). Many other factors affect the semen characteristics, including nutrition, social environment, the presence of females, geographical location, age, testicle and body conformation, libido and management system, as reported in many studies (Mandiki et al., 1998; Al-Ghalban et al., 2004; Zamiri and Khodaei, 2005; Zarazaga et al., 2005), but the PTP and the breed are primary factors regulating the seasonal reproduction. Therefore, they became preference for many researchers (Simplicio et al., 1982; Ibrahim, 1997; Kafi et al., 2004; Barkawi et al., 2006; Talebi et al., 2009; Zamiri et al., 2010).

The Arkhar-Merino is a breed of sheep obtained by crossbreeding between wild Arkhar rams with ewes of the Novocaucasian Merino, Précoce and Rambouillet breeds (Ernst and Dmitriev, 2007). These two genetic groups are developed targeting the improvement of local breeds (Baluchi and Moghani) for wool traits. There is no published information on the seasonal variation of seminal traits of Baluchi $\times$ Moghani and Arkharmerino $\times$ Moghani genetic groups. In addition to gathering information on reference values for semen characteristics, evaluation of the effects of PTP on ram semen characteristics at this latitude was another pursuit for this study, along with the evaluation of putative differences on semen traits between the two genetic groups, to identify the most suitable line for breeding purposes. In intensive management systems, a significant number of ewes are inseminated in nonbreeding season (Colas et al., 1988, 1990).

Therefore, detection of semen characteristic of the crosses in non-breeding season is necessary. Although, information is available on the physicochemical parameters of semen of the crosses and on the part of their reproductive traits (Moghaddam et al., 2012; Asadpour et al., 2012; 2012a), however, this yearlong research is the first report on the seasonal variation of semen characteristics of these crossbreed rams reared at the northwest of Iran.

\section{MATERIALS AND METHODS}

\section{Location}

This trial was performed at the Sheep Breeding Research Center, Tabriz $\left(38^{\circ} 02^{\prime} \mathrm{N}, 46^{\circ} 27^{\prime} \mathrm{E}\right.$ and an altitude of $1567 \mathrm{~m}$ above sea level), Iran. This experiment was carried out from October 2010 to September 2011.

\section{Animals}

Ten crossbreed and fertile rams consisting of $5 \mathrm{BL} \times \mathrm{MG}$ and $5 \mathrm{AM}$ $\times$ MG aged 3 to 6 years and with a live weight of 74 to $88 \mathrm{~kg}$ were used in this study. The animals were maintained under natural PTP and equal levels of nutrition per day; $20 \%$ concentrate ( $75 \%$ barley, $25 \%$ corn, soya, bran) and $80 \%$ alfalfa hay. The rams were initially trained (beginning of September) for 15 days in September to ejaculate semen by using artificial vagina $(A V)$ in the mating pen $(210 \mathrm{~cm}$ in length, $60 \mathrm{~cm}$ in width and $120 \mathrm{~cm}$ in height). Training and semen sampling was performed via an anoestrous teaser with quiet temperament. The rams were separated of the herd and housed in a large cover shelter with an open precinct for walking freely. All rams were sent to drink fresh water twice or three times a day. The other general management was checked during the study. The climate conditions of the research center were recorded during the experiment (Table 1).

\section{Semen collection}

Randomly, all the rams were divided into the two groups. Each group included 5 rams of different genetic groups. Semen collection 
Table 2. Semen characteristics in $B L \times M G$ and $A M \times M G$ genetic group over the year.

\begin{tabular}{|c|c|c|c|c|c|c|c|c|c|c|c|c|}
\hline $\begin{array}{l}\text { Genetic } \\
\text { Group }\end{array}$ & & $\begin{array}{l}\text { SV } \\
(\mathrm{ml})\end{array}$ & $\begin{array}{l}\text { WM } \\
(0-5)\end{array}$ & $\begin{array}{l}\text { PM } \\
(\%)\end{array}$ & $\begin{array}{c}\text { SC } \\
(0-5)\end{array}$ & $\begin{array}{c}\text { TSE } \\
\left(\times 10^{9}\right) \\
\end{array}$ & $\begin{array}{l}\text { Conc } \\
\left(\times 10^{9}\right)\end{array}$ & $\begin{array}{l}\text { SL } \\
(\%)\end{array}$ & $\begin{array}{c}\text { SAB } \\
(\%)\end{array}$ & $\begin{array}{c}\text { SI } \\
\left(\times 10^{9}\right) \\
\end{array}$ & $\mathrm{pH}$ & MBRT (s) \\
\hline \multirow{5}{*}{$B L \times M G$} & $\mathrm{~N}$ & 334 & 334 & 334 & 334 & 334 & 334 & 334 & 332 & 334 & 333 & 331 \\
\hline & Mean & 0.86 & 3.72 & 67.42 & 3.73 & 3.55 & 3.77 & 68.91 & 13.02 & 14769 & 6.54 & 119.39 \\
\hline & S.E. & 0.08 & 0.09 & 1.70 & 0.16 & 0.33 & 0.17 & 1.60 & 0.76 & 1823.50 & 0.09 & 3.10 \\
\hline & Min & 0.45 & 2.00 & 40.00 & 2.00 & 0.916 & 1.95 & 45.00 & 4.00 & 722.40 & 5.70 & 65.00 \\
\hline & Max & 1.40 & 5.00 & 85.00 & 5.00 & 18.90 & 5.68 & 90.00 & 26.00 & 43834.50 & 8.20 & 230.00 \\
\hline \multirow{5}{*}{$\mathrm{AM} \times \mathrm{MG}$} & $\mathrm{N}$ & 334 & 334 & 334 & 334 & 334 & 334 & 334 & 330 & 334 & 334 & 331 \\
\hline & Mean & 1.02 & 3.93 & 72.79 & 3.55 & 4.495 & 3.516 & 74.57 & 10.95 & 19472.29 & 6.57 & 111.70 \\
\hline & S.E. & 0.08 & 0.09 & 1.59 & 0.16 & 0.327 & 0.182 & 1.57 & 0.71 & 1767.06 & 0.09 & 3.17 \\
\hline & Min & 0.45 & 2.00 & 45.00 & 1.00 & 0.985 & 0.960 & 50.00 & 3.00 & 1395.2 & 5.90 & 45.00 \\
\hline & Max & 1.90 & 5.00 & 90.00 & 5.00 & 31.55 & 5.81 & 94.00 & 21.00 & 104058 & 7.80 & 220.00 \\
\hline
\end{tabular}

SV: Semen volume, WM: wave motion, PM: progressive motility, SC: semen color, TSE: total spermatozoa per ejaculate, Conc: spermatozoa concentration, SL: percentage of live spermatozoa, SAB: percentage of abnormal spermatozoa, SI: semen index. MBRT: methylene blue reduction time.

was done for every 2 days from 5 rams. Ejaculation intervals of each ram were five days throughout the study. Short form AV was used for semen collection. Collecting glass of $\mathrm{AV}$ was warmed at $37^{\circ} \mathrm{C}$ before the operation and was maintained at this temperature until processed. Immediately, the fresh samples were transferred to the laboratory (avoiding sunlight) and were surveyed.

\section{Semen appraising}

Seminal traits of the fresh semen were evaluated according to the procedure adopted by Evans and Maxwell (1987). Volume of ejaculates was measured in a conical tube graduated at $0.1 \mathrm{ml}$ intervals. Semen $\mathrm{pH}$ was surveyed with two methods, a) pen form $\mathrm{pH}$-meter (with 0.1 grades, model 8685, AZ Instrument, Taiwan), b) indicator pH-meter strips (Merck, made in Germany). SC was determined by use of a Thoma slide (haemocytometer method). The fresh semen was diluted using $0.1 \mathrm{M}$ sodium citrate dehydrate $2.9 \%(\mathrm{pH}=6.7-6.9)$ plus one drop of formalin (1: 400) at 400x magnification under a microscope. TSE was then calculated (volume $\times$ density). WM was evaluated according to the stuyd of Evans and Maxwell (1987). The assessment of the PM was a visual scale from 0 to $100 \%$ on basis of suspended droplet slide and on a heated $\left(37^{\circ} \mathrm{C}\right)$ stage using phase-contrast optics $(400 x)$. The evaluation was done in increments of 5 to 10 percentage points for viewing individual spermatozoa with more lucidity and estimating PM. For SAB and LS, semen was stained with eosin-nigrosin stain and examined microscopically $(400 x)$. From several parts of the slide, about 300 spermatozoa were evaluated for mortality and 200 for SAB percentages. Metabolic activity of spermatozoa was measured by MBRT method based on color change from blue to colorless at $37^{\circ} \mathrm{C}$. In a thin and transparent tube (1 $\mathrm{mm}$ diameter), $0.2 \mathrm{ml}$ semen was added to $0.2 \mathrm{ml}$ of methylene blue and time for color change was recorded. SI (volume $\times \mathrm{SC} / \mathrm{ml} \times \mathrm{LS} \% \times \mathrm{PM} \%$ ) was calculated, as an indicator for appraising semen quality.

\section{Statistical analysis}

All statistical analysis were performed using the MIXED Procedure of Statistical Analysis System (SAS, 1996) and outliers deleted for volume, concentration, abnormality and MBRT traits. Values were considered to be statistically significant at $\mathrm{P} \leq 0.05$. For volume, $\mathrm{SC}$, abnormality and
MBRT traits, the outlier data was deleted. Means values were compared with Tukey test. Pearson correlation coefficient was calculated to evaluate the relationship between quality and quantity of semen attributes.

\section{RESULTS}

The quantity traits of semen (semen volume, color, SC and TSE; Table 2) were significantly influenced by season of the year. In AM $\times M G$ and $\mathrm{BL} \times \mathrm{MG}$ genetic groups, minimum and maximum values of semen volume were recorded at spring and autumn, respectively $(P<0.01)$. Frequently, semen volume increased from end of June and received the highest values at the October, and again decreased gradually at the end of October. This falling process continued during autumn and winter except for $B L \times M G$ that had a sudden increase in April (Figure 1). The highest mean vales of LS were recorded in December (in BL $\times$ $M G$ ) and September (in $M R \times M G)$. In $A M \times M G$ 


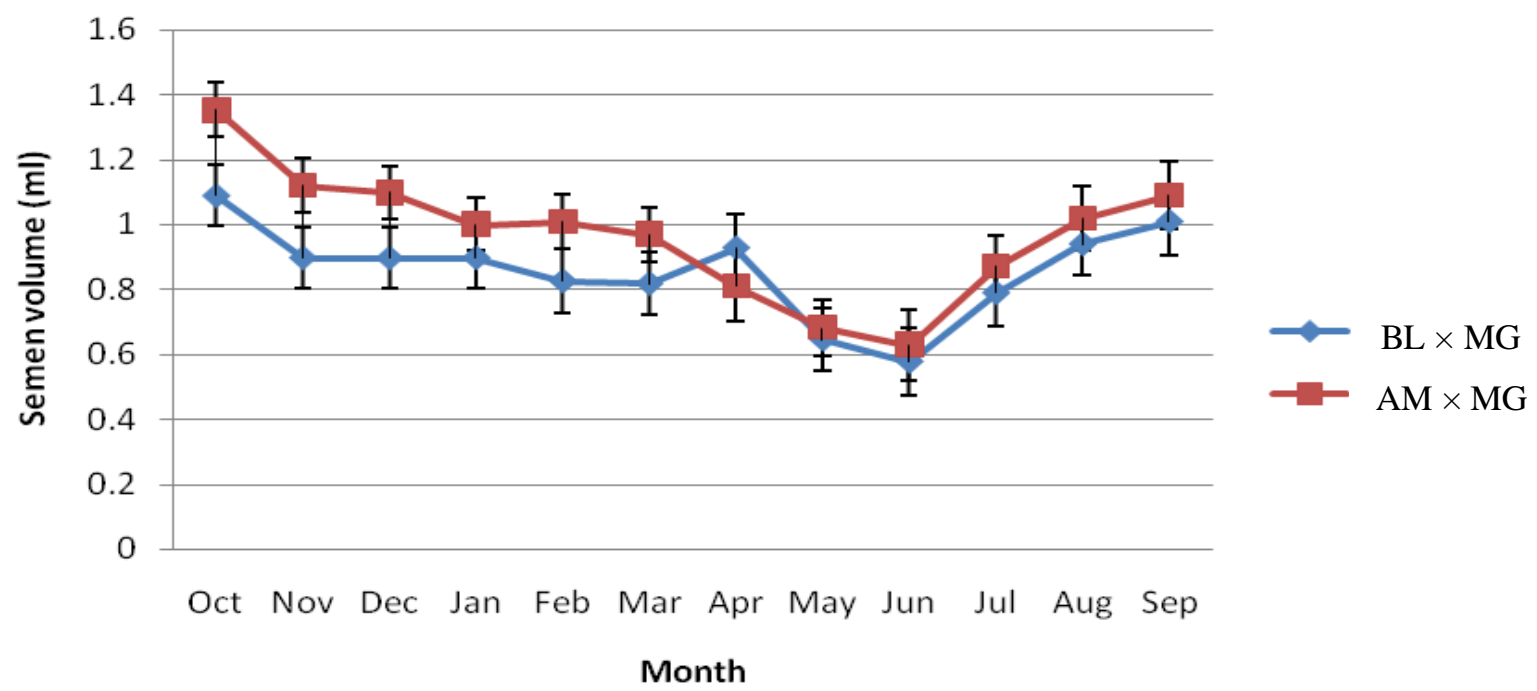

Figure 1. Monthly variations of semen volume in the two genetic groups throughout the year.

rams the significant differences was observed between the spring (the part of non-breeding season) and the other seasons $(P<0.01)$. But $B L \times M G$ rams had a significant difference between non-breeding season (spring and winter) and breeding season $(P<0.01)$. In the two genetic groups SC, TSE and semen color were highest in winter and the lowest was in spring. In the crosses, spring was the peak for semen $\mathrm{pH}$. In $\mathrm{BL} \times \mathrm{MG}$ rams, mean values of semen $\mathrm{pH}$ increased concurrent with the spring. The most SI was observed during autumn (in both genetic group observed at October) and the lowest mean values was in spring (especially June). In $A M \times M G$ rams, there was significant difference in WM between breeding season (summer and autumn) and non-breeding season (Table 3). But most mean values in $B L \times M G$ rams were recorded in summer and the fewest were in winter $(P<0.01)$.

The results in the $A M \times M G$ and $B L \times M G$ rams demonstrated that individual progressive motility of spermatozoa was higher in breeding seasons (autumn and summer). In $A M \times M G$ genetic group, greatest value synchronized with the October $(75.09 \pm 1.53)$ and the lowest was in January (69.78 \pm 1.58$)$. In GH $\times$ BL genetic group, the highest levels were recorded in September $(71.1 \pm 1.59)$ and lowest in June $(62.43 \pm 1.70)$. The highest and lowest percentage of live spermatozoa in $\mathrm{BL}$ $\times$ MG genetic group were recorded in September (71.56 $\pm 1.56)$ and June $(64.66 \pm 1.65)$, respectively. But the highest and lowest $L S$ in $A M \times M G$ rams were recorded in October $(75.59 \pm 1.54)$ and February $(71.43 \pm 1.51)$, respectively (Figure 2 ). In our study, the tail abnormalities were the most spermatozoa abnormality that occurred. In spite of these facts, semen quality from the viewpoint of sperm normality improved significantly during autumn in $A M \times M G$ and summer in $B L \times M G$ genetic groups. The season and genetic group did not influence the rate of metabolic activity and $W M(P>0.05)$. The $B L \times M G$ genetic group showed the lowest MBRT in autumn and $A M \times M G$ group in summer. Correlation coefficients between various semen characteristics (Table 4) exhibited a near relationship between LS and motility traits $(r=0.90, P<0.01)$ and sperm density and semen color $(r=0.30, P<0.01)$. Semen volume showed a positive correlation with SC, color and TSE $(r=0.21,0.24$ and 0.39 , respectively). The MBRT decreased over time and correlated with all semen traits $(P<0.01)$. SAB was correlated with all the semen quantity traits, except for TSE. The percentage of abnormal spermatozoa was significantly correlated with $\mathrm{WM}(\mathrm{r}=-0.69, \mathrm{P}<0.01)$, PM $(r=-0.88, P<0.01)$ and $L S(r=-0.92, P<0.01)$. WM and individually progressive motility of semen samples showed a significant correlation with semen density $(r=$ 0.19 and $r=0.33$, respectively) and semen $\mathrm{pH}(\mathrm{r}=-0.38$ and $r=-0.39$, respectively). Moreover, semen $\mathrm{pH}$ showed high negative correlation with $\mathrm{SC}(r=-0.6, \mathrm{P}<0.01)$.

\section{DISCUSSION}

As expected, the summer and autumn with decreasing daylight length (breeding season) and winter and spring seasons with increasing daylight length (non-breeding season), affected the seminal indices of the crossbreed rams. The effect of season and/or PTP on seminal traits has been previously reported in different breeds of rams (Karagiannidis et al., 2000; Kafi et al., 2004; Zamiri and Khodaei, 2005; Deldar Tajangookeh et al., 2007; Zamiri et al., 2010) and also in other seasonal breeding animals such as buck (Barkawi et al., 2006; Karagiannidis et al., 1999) and stallion (Janett et al., 2003). Among quality traits, a significant effect of season was recorded on $S A B$, semen $\mathrm{pH}(\mathrm{P}<0.05)$ and $\mathrm{SI}(\mathrm{P}<0.01)$. PM, LS and 
Table 3. Seasonal variations in semen characteristics (mean \pm S.E.) of Baluchi $\times$ Moghani $(B L \times M G)$ and Arkharmerino $\times$ Moghani $(A M \times M G)$ rams .

\begin{tabular}{|c|c|c|c|}
\hline Semen characteristics & Season & BL $\times$ MG (Mean \pm S.E.) & AM $\times$ MG (Mean $\pm S . E)$. \\
\hline \multirow{5}{*}{ Total sperm/ejaculate $\left(\times 10^{9}\right)$} & Spring & $2.430 \pm 0.430^{\mathrm{b}}$ & $2.326 \pm 0.463^{\mathrm{C}}$ \\
\hline & Summer & $3.210 \pm 0.298^{a}$ & $3.730 \pm 0.290^{b}$ \\
\hline & Autumn & $3.636 \pm 0.316^{a}$ & $4.336 \pm 0.285^{b}$ \\
\hline & Winter & $4.105 \pm 0.306^{\mathrm{a}}$ & $5.853 \pm 0.306^{\mathrm{a}}$ \\
\hline & Mean & $3.345 \pm 0.337$ & $4.061 \pm 0.336$ \\
\hline \multirow{5}{*}{ Sperm concentration $\left(\times 10^{9}\right)$} & Spring & $3.443 \pm 0.195^{b}$ & $3.315 \pm 0.199^{b}$ \\
\hline & Summer & $3.625 \pm 0.177^{\mathrm{ab}}$ & $3.555 \pm 0.185^{\mathrm{ab}}$ \\
\hline & Autumn & $3.796 \pm 0.176^{\mathrm{a}}$ & $3.482 \pm 0.176^{\mathrm{ab}}$ \\
\hline & Winter & $3.952 \pm 0.180^{\mathrm{a}}$ & $3.676 \pm 0.179^{\mathrm{a}}$ \\
\hline & Mean & $3.704 \pm 0.182$ & $3.507 \pm 0.184$ \\
\hline \multirow{5}{*}{ Semen volume (ml) } & Spring & $0.69 \pm 0.09^{c}$ & $0.70 \pm 0.09^{b}$ \\
\hline & Summer & $0.90 \pm 0.08^{\mathrm{a}}$ & $1.02 \pm 0.08^{\mathrm{a}}$ \\
\hline & Autumn & $0.96 \pm 0.09^{\mathrm{a}}$ & $1.15 \pm 0.09^{\mathrm{a}}$ \\
\hline & Winter & $0.84 \pm 0.09^{b}$ & $1.06 \pm 0.08^{\mathrm{a}}$ \\
\hline & Mean & $0.84 \pm 0.09$ & $0.98 \pm 0.08$ \\
\hline \multirow{5}{*}{ Semen color $(0-5)$} & Spring & $3.351 \pm 0.171^{\mathrm{c}}$ & $3.326 \pm 0.177^{b}$ \\
\hline & Summer & $3.512 \pm 0.156^{\mathrm{bc}}$ & $3.419 \pm 0.173^{\mathrm{ab}}$ \\
\hline & Autumn & $3.712 \pm 0.159^{\mathrm{ab}}$ & $3.566 \pm 0.158^{\mathrm{ab}}$ \\
\hline & Winter & $3.979 \pm 0.161^{a}$ & $3.671 \pm 0.161^{a}$ \\
\hline & Mean & $3.638 \pm 0.162$ & $3.495 \pm 0.167$ \\
\hline \multirow{5}{*}{ Wave motion $(0-5)$} & Spring & $3.60 \pm 0.10^{b c}$ & $3.81 \pm 0.09^{b}$ \\
\hline & Summer & $3.92 \pm 0.09^{\mathrm{a}}$ & $4.00 \pm 0.09^{\mathrm{a}}$ \\
\hline & Autumn & $3.72 \pm 0.09^{\mathrm{ab}}$ & $4.05 \pm 0.11^{\mathrm{a}}$ \\
\hline & Winter & $3.51 \pm 0.11^{\mathrm{c}}$ & $3.75 \pm 0.09^{b}$ \\
\hline & Mean & $3.68 \pm 0.09$ & $3.90 \pm 0.09$ \\
\hline \multirow{4}{*}{ Progressive motility (\%) } & Spring & $65.37 \pm 1.61^{b}$ & $72.00 \pm 1.75^{\mathrm{a}}$ \\
\hline & Summer & $70.51 \pm 1.54^{\mathrm{a}}$ & $74.67 \pm 1.61^{\mathrm{a}}$ \\
\hline & Autumn & $69.89 \pm 1.50^{\mathrm{a}}$ & $74.89 \pm 1.50^{\mathrm{a}}$ \\
\hline & Winter & $64.40 \pm 1.73^{\mathrm{b}}$ & $71.00 \pm 1.54^{\mathrm{a}}$ \\
\hline \multirow{6}{*}{ Live spermatozoa (\%) } & Mean & $67.54 \pm 1.70$ & $73.14 \pm 1.59$ \\
\hline & Spring & $65.91 \pm 1.68^{\mathrm{C}}$ & $73.33 \pm 1.67^{\mathrm{a}}$ \\
\hline & Summer & $70.37 \pm 1.66^{\mathrm{ab}}$ & $75.73 \pm 1.66^{\mathrm{a}}$ \\
\hline & Autumn & $70.96 \pm 1.51^{\mathrm{a}}$ & $75.26 \pm 1.51^{\mathrm{a}}$ \\
\hline & Winter & $66.54 \pm 1.54^{\mathrm{bc}}$ & $72.28 \pm 1.51^{\mathrm{a}}$ \\
\hline & Mean & $68.44 \pm 1.60$ & $74.16 \pm 1.57$ \\
\hline \multirow{4}{*}{ Abnormal sperm (\%) } & Spring & $12.71 \pm 0.76^{\mathrm{ab}}$ & $11.47 \pm 0.75^{\mathrm{a}}$ \\
\hline & Summer & $11.86 \pm 0.70^{b}$ & $9.67 \pm 0.67^{b}$ \\
\hline & Autumn & $12.65 \pm 0.74^{\mathrm{ab}}$ & $9.11 \pm 0.73^{b}$ \\
\hline & Winter & $14.04 \pm 0.75^{\mathrm{a}}$ & $10.84 \pm 0.77^{\mathrm{a}}$ \\
\hline \multirow{6}{*}{ Semen index $(\times 109)$} & Mean & $12.81 \pm 0.74$ & $10.27 \pm 0.72$ \\
\hline & Spring & $11346 \pm 1859.61 \mathrm{~b}$ & $12123 \pm 1854.65 b$ \\
\hline & Summer & $16511 \pm 1881.39 a$ & $19852 \pm 1769.43 a$ \\
\hline & Autumn & $17249 \pm 1813.56 a$ & $22645 \pm 1827.49 a$ \\
\hline & Winter & $14023 \pm 1797.32 \mathrm{ab}$ & $20071 \pm 1769.46 a$ \\
\hline & Mean & $14782 \pm 1837.97$ & $18672 \pm 1805.25$ \\
\hline
\end{tabular}


Table 3. Continued.

\begin{tabular}{llll}
\hline & Spring & $6.88 \pm 0.10^{\mathrm{a}}$ & $6.69 \pm 0.11^{\mathrm{a}}$ \\
Semen pH & Summer & $6.42 \pm 0.09^{\mathrm{b}}$ & $6.60 \pm 0.10^{\mathrm{a}}$ \\
& Autumn & $6.37 \pm 0.11^{\mathrm{b}}$ & $6.57 \pm 0.09^{\mathrm{ab}}$ \\
& Winter & $6.51 \pm 0.10^{\mathrm{b}}$ & $6.51 \pm 0.09^{\mathrm{b}}$ \\
& Mean & $6.54 \pm 0.10$ & $6.59 \pm 0.09$ \\
MBRT (sec) & & \\
& Spring & $120.22 \pm 3.61^{\mathrm{a}}$ & $111.18 \pm 3.70^{\mathrm{a}}$ \\
& Summer & $110.74 \pm 3.77^{\mathrm{a}}$ & $106.27 \pm 3.11^{\mathrm{a}}$ \\
& Autumn & $116.69 \pm 3.81^{\mathrm{a}}$ & $108.33 \pm 3.20^{\mathrm{a}}$ \\
& Winter & $123.47 \pm 3.17^{\mathrm{a}}$ & $116.08 \pm 3.25^{\mathrm{a}}$ \\
& Mean & $117.78 \pm 3.59$ & $110.46 \pm 3.31$ \\
\hline
\end{tabular}

a, b, c Means in the column of each parameter with different superscripts differ significantly $(P<0.05)$. Means within each column within each factor having the same letter does not differ significantly from each other $(P<0.05)$.

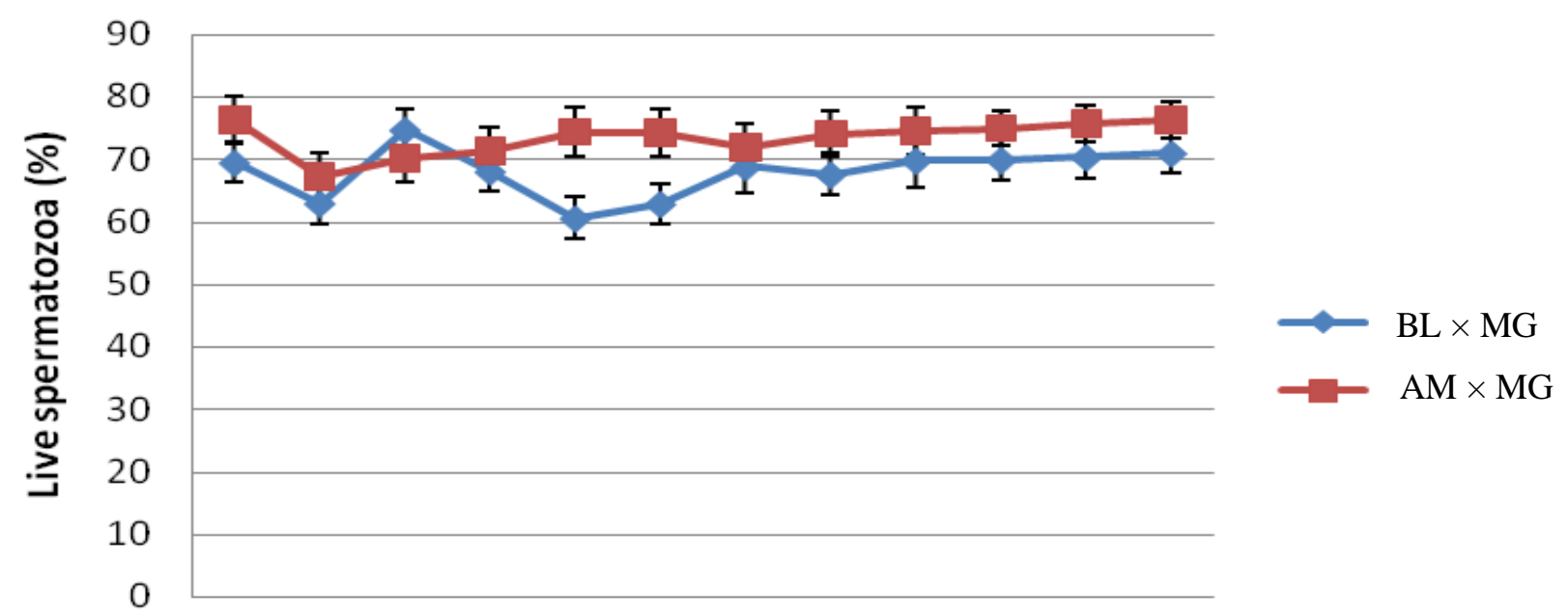

Oct Nov Dec Jan Feb Mar Apr May Jun Jul Aug Sep

Figure 2. Monthly variations of live spermatozoa in two the genetic groups throughout the year.

Table 4. Correlation coefficients between various seminal traits of the rams.

\begin{tabular}{|c|c|c|c|c|c|c|c|c|c|c|}
\hline Parameter & MBRT & $\mathrm{pH}$ & SI & SAB & SL & Conc & TSE & Color & PM & WM \\
\hline SV & $-0.21^{\star \star}$ & $-0.20^{\star \star}$ & $0.71^{* *}$ & -0.10 & $0.13^{*}$ & $0.21^{* *}$ & $0.39^{*}$ & $0.24^{\star *}$ & $0.15^{\star \star}$ & $0.21^{\star \star}$ \\
\hline WM & $-0.76^{* *}$ & $-0.38^{* *}$ & $0.50^{* *}$ & $-0.69^{* *}$ & $0.74^{* *}$ & $0.19^{* *}$ & $0.19^{*}$ & $0.37^{* *}$ & $0.78^{\star *}$ & \\
\hline PM & $-0.84^{* *}$ & $-0.39^{\star *}$ & $0.59^{* *}$ & $-0.88^{* *}$ & $0.90^{* *}$ & $0.33^{* *}$ & $0.11^{*}$ & $0.34^{\star *}$ & & \\
\hline Color & $-0.67^{\star *}$ & $-0.56^{\star \star}$ & $0.57^{\star *}$ & $-0.31^{*}$ & $0.30^{\star *}$ & $0.92^{* *}$ & $0.34^{\star *}$ & & & \\
\hline TSE & $-0.22^{* *}$ & $-0.17^{\star}$ & $0.41^{* *}$ & -0.05 & 0.09 & 0.29 ** & & & & \\
\hline Conc & $-0.67^{* *}$ & $-0.60^{* *}$ & $0.61^{* *}$ & $-0.28^{*}$ & $0.30^{* *}$ & & & & & \\
\hline SL & $-0.81^{* *}$ & $-0.35^{\star}$ & $0.57^{\star *}$ & $-0.92^{* *}$ & & & & & & \\
\hline SAB & $0.80^{* *}$ & $0.29^{* *}$ & $-0.54^{\star *}$ & & & & & & & \\
\hline SI & $-0.67^{* *}$ & $-0.30^{\star *}$ & & & & & & & & \\
\hline $\mathrm{pH}$ & $0.52^{\star *}$ & & & & & & & & & \\
\hline
\end{tabular}

*Significant at $P<0.05,{ }^{*}$ Significant at $P<0.01$, coefficients without symbol $\left({ }^{*}\right.$ or $\left.{ }^{*}\right)$ are not significant. SV: semen volume, WM: wave motion, PM: progressive motility, TSE: total spermatozoa per ejaculate, Conc: spermatozoa concentration, SL: percentage of live spermatozoa, SAB: percentage of abnormal spermatozoa, SI: semen index. MBRT: Methylene blue reduction time. 
MBRT did not have significantly seasonal variations. Moreover, effect of PTP was also observed clearly on semen quantity characteristics $(P<0.01)$. These seasonal variations in semen quality and quantity were attributive mainly to changes in daylight length throughout the year (Chemineau et al., 1992). No significant difference was found on all traits between the two genetic groups $(P>0.05)$. Significant differences among the rams within each genetic group $(P<0.05)$ were found in some of the seminal traits, but, non-significant differences were found between the two genetic groups in any of the other traits which is consistent with the previous reports (Karagiannidis et al., 2000). Our results on mean values of semen characteristics are in agreement with those of other researchers (Zamiri et al., 2010; Gundogan, 2007; Kafi et al., 2004; Ghalban et al., 2004; Karagiannidis et al., 2000). The semen volume of 0.60 to $1.6 \mathrm{ml}$, SC of 2.6 to $5.5 \times 10^{9}$, SAB of 4 to $29 \%$ and live or motile spermatozoa of 60 to $90 \%$ is on record (Karagiannidis et al., 2000; Kafi et al., 2004; Gundogan, 2007).

Therefore, it could be accepted that there is wide amplitude of semen traits in several breeds of ram. In the current study, mean values for the SAB (9 to 14\%) were generally higher than that of other researchers (Karagiannidis et al., 2000) for Chios and Friesian rams and for Akkarman and Awassi rams (Gundogan, 2007). Zamiri et al. (2010) reported in Moghani breed a minimum SAB of $7.9 \%$ in September much which is lesser than the value observed in our study, $11.42 \%$ in $\mathrm{BL} \times \mathrm{GH}$ rams in September and $8.91 \%$ in the $\mathrm{AM} \times \mathrm{MG}$ genetic group in November. LS in the two genetic groups was lower than the values recorded by Kafi et al. (2004) in Iran $\left(29^{\circ} 25^{\prime} \mathrm{N}, 52^{\circ} 46^{\prime} \mathrm{E}\right)$. The semen volume in the $\mathrm{BL} \times$ MG $(0.84 \pm 0.09)$ did not coincide with the results of Kafi et al. (2004) and was lower $(1.03 \pm 0.08)$ in $\mathrm{AM} \times \mathrm{GH}$ rams than reported value (Kafi et al., 2004) making the comparison of seminal attributes often difficult. Thus, it is not surprising that wide variations have been reported in the seminal attributes of rams (Gundogan, 2007; Zamiri and Khodaei, 2005; Kafi et al., 2004; Karagiannidis et al., 2000). In BL $\times$ GH genetic group, the SC remained high $(3.952 \pm 0.180)$ during winter and low in spring (3.443 \pm $0.195)$, summer $(3.625 \pm 0.177)$ and autumn (3.796 \pm $0.176)$, a trend comparable to that reported by Karagiannidis et al. (2000) and Talebi et al. (2009). These findings confirmed the previous records of seasonal variations of $S C$ in $B L \times M G$ rams at $38^{\circ} \mathrm{N}$ latitude. In both crosses, circumstance of seasonal fluctuations of semen color and SC was similar. In our study, most of the mean values for the semen characteristics of $B L \times M G$ and $A M \times M G$ rams, were almost similar to those reported by other authors (Barkawi et al., 2006; Zamiri et al., 2010; Gundogan, 2007), in similar temperate regions. The semen quantity and quality attributes in the crossbreed rams differed in breeding (late summer to middle of autumn) and nonbreeding seasons. SC did not follow a quite similar trend with that of the ejaculate volume in this study and was comparable with the results obtained by Talebi et al. (2009). Mean values of MBRT in our study were quite different with the reports of Galal et al. (1978) in Egypt. $\mathrm{BL} \times \mathrm{MG}$ and $\mathrm{AM} \times \mathrm{MG}$ rams had best performance in breeding seasons. Galal et al. (1978) recorded in their study on Merino, Ossimi and their crosses the best metabolic activity in spring (76.8 $\pm 1.04 \mathrm{~s})$ and autumn $(77.2 \pm 1.04 \mathrm{~s})$. While summer $(102.2 \pm 1.04 \mathrm{~s})$ had the greatest mean values in these breeds. On the contrary, Galal et al. (1978) did not observe significant difference in MBRT traits between several seasons of the year.

In the present study, the semen characteristics were generally better towards the end of summer (onset of improvement) and in the two first months of autumn, than during the winter (onset of decrease in quality) and spring (usually with lowest quality and quantity). In both genetic groups, PM was lowest in winter and spring in contrast to the findings of Karagiannidis et al. (2000) at $40^{\circ} \mathrm{N}$. The data suggest that summer and autumn with decreasing daylight length and winter and spring with increasing daylight length influenced the seminal traits of $B L \times M G$ and $A M \times M G$ rams. PTP effects on seasonal breeders have been reported to be determined by the latitude at which they are kept. At latitudes above $40^{\circ} \mathrm{N}$, marked variations in seminal traits and increased sperm production with decreasing daylight length have been observed (Zamiri et al., 2010). Seasonal variations, although less marked, were observed between 30 and $40^{\circ} \mathrm{N}$ latitude, with higher sperm production during the summer and autumn (Corteel, 1977). Although, the crossbreed rams were capable of ejaculating throughout the year, Rosa and Bryant (2003) illustrated that seasonal breeding animals occurred in middle latitudes. High correlation between WM and sperm progressive motility with live sperm $(r=0.74, r=0.90, P<0.01$, respectively) demonstrated that concurrent with improved PM (as one of the most important semen quality indicators) there is increased LS which resembled the findings of Kafi et al. (2004). The significant correlation found between motility and TSE is in agreement with the results of Kafi et al. (2004). A high negative correlation of MBRT with motility traits $(r=-0.76$ to $r=-0.84, P<0.01)$ was similar to the findings of Chandler et al. (2000) but was inconsistent with the results of Kishk (2008). MBRT is an evaluator of the metabolic status of the spermatozoa (Salisbury et al., 1978).

The observed high negative correlation between SC and MBRT $(r=-0.67, P<0.01)$ and between MBRT and LS $(r=-0.81, P<0.01)$ were similar to the findings of Kishk (2008). This can be attributed to the rate of release of hydrogen upon fructose utilization by sperm cells. Thus, these samples might become acidic and not reliable for long-term storage. Most relationship among semen traits with semen $\mathrm{pH}$ could be well correlated with SC and color $(r=-0.60$ and $-0.56, P<0.01)$, and watery sample that is alkaline. Among the quantitative traits, a 
high correlation between MBRT with color and SC was observed. Karagiannidis et al. (2000) also reported a significant correlation between SC and SAB $(r=-0.19, P$ $<0.05$ ). The results of the present investigations suggest that ewes exhibiting estrus could be artificially inseminated by fresh semen throughout the year and consequently, reproductive performance of herd increased considerably. Seasonal fluctuations of environmental conditions markedly influenced reproduction of animals at higher latitudes and altitudes (Rosa and Bryant, 2003). Robinson (1981) argued that breeds located between $35^{\circ} \mathrm{N}$ and have the tendency to breed at all times of the year. Evans and Maxell (1987) reported 30 and $40^{\circ} \mathrm{N}$ latitudes for the breeds to follow this tendency. Latitudes above $35^{\circ} \mathrm{N}$ (Hafez, 1952; Goot, 1969) or higher than $40^{\circ} \mathrm{N}$ (Talebi et al., 2009; Zamiri et al., 2010) considerably influenced the seminal traits.

However, in some studies, for example in Jordan (at $31.5^{\circ} \mathrm{N}$ in Damascus bucks) and Iran $\left(34^{\circ} 18^{\prime} \mathrm{N}, 47^{\circ} 3^{\prime} \mathrm{E}\right.$ in Markhoz bucks) the PTP was found to have significant effect on breeding behaviour of sheep. In temperate latitudes $\left(40\right.$ to $\left.50^{\circ} \mathrm{N}\right)$ sperm production of rams is a continuous process, although the total number of sperm produced per testis is usually higher in autumn than in spring (Dacheux et al., 1981). The present study showed that the reproductive activity of the seasonal breeding animals example, rams, may be improved by exploitation of PTP synchronized circannual reproductive rhythm (endogenous mechanisms) and exogenous factors. Reproductive activity is not a direct function of day length, but is affected by the photoperiodic history of the animal, the direction of photoperiodic changes and the stage of the circannual rhythm at which a photoperiodic signal is received (Robinson and Karsch, 1987; Gorman and Zucker, 1995a). Our study clearly showed linkage between PTP and reproduction of $B L \times M G$ and $A M \times$ $M G$ genetic groups located at $38^{\circ} 02^{\prime} \mathrm{N}, 46^{\circ} 27^{\prime} \mathrm{E}$ in Iran.

\section{Conclusion}

Semen evaluation does have an important role in Al programs or in flocks where single sire joining groups are used. This will be useful for identifying rams with poor performers. Thus, it will provide optimum breeding selection of males in herd. The seminal traits of $B L \times M G$ and $A M \times M G$ rams in Northwest of Iran showed a significant seasonal variation in semen characteristics. The best semen is produced during late summer to November. Nonetheless, the magnitude of these seasonal effects should not prevent the animals from been used for semen collection for Al throughout the year. But it is necessary to perform semen evaluation on an individual basis for every ram used for Al or breeding.

\section{REFERENCES}

Al-Ghalban AM, Tabbaa MJ, Kridli RT (2004). Factors affecting semen characteristics and scrotal circumference in Damascus bucks. Small Rum. Res. 53:141-149.

Asadpour R, Pourseif MM, MoghAddam GH, Jafari SR, Tayefi H, Mahmodi $H$ (2012). Effect of vitamin B12 addition to extenders on some physicochemical parameters of semen in crossbred rams. Afr. J. Biotechnol. 11:11741-11745.

Asadpour R, Pourseif MM, MoghAddam GH, Tayefi H (2012a). Activity of antioxidant enzymes and malondialdehyde in seminal plasma and their relationship with semen characteristics in crossbred rams. Indian J. Anim. Sci. 82:710-712.

Aurich C, Burgmann F, Hoppe H (1996). Opioid regulation of luteinizing hormone and prolactin release in the horse-identical or independent endocrine pathways? Animal Reprod. Sci. 44:127-134.

Barkawi AH, Elsayed EH, Ashour G, Shehata E (2006). Seasonal changes in semen characteristics, hormonal profiles and testicular activity in Zaraibi goats. Small Rum. Res. 66:209-213.

Candler JE, Harrison CM, Canal AM (2000). Spermatozoal methylene blue reduction: an indicator of mitochondrial function and its correlation with motility. Theriogenology 54:261-271.

Chemineau P, Malpaux B, Delgadillo JA, Guerin Y, Ravault JP, Thimonier J, Pelletier J (1992). Control of sheep and goats reproduction: use of light and melatonin. Anim. Reprod. Sci. 30:157184.

Colas G, Lefebvre J, Guerin J (1988). Recherche d'une prevision precoce de l'amplitude des variations saisonnieres du diameter testiculaire et du pourcentage de spermatozoids anormaux chez le belier Ile-de-France: 1. Animaux nes en fevrier. Reprod. Nutr. Dev. 28:589-601.

Colas G, Lefebvre J, Guerin J (1990). Father-male offspring transmission of seasonal variations in testis diameter and percentage of abnormal sperm in the lle-de-France rams: male offspring born in February. Reprod. Nutr. Dev. 30:589-603.

Corteel JM (1977). Production, storage and insemination of goat semen. Management of Reproduction in Sheep and Goat symposium. University of Wisconsin, Madison, pp. 41-57.

Dacheux JL, Pisselet C, Blanc MR, Hocherau-de-Reviers MT, Courot M (1981). Seasonal variation in rete testis fluid secretion and sperm production in different breeds of rams. J. Reprod. Fert. 61:363-371.

Deldar Tajangookeh $\mathrm{H}$, Zare shahneh A, Moradi shahrebabak M, Shakeri M (2007). Monthly variation of plasma concentration of testosterone and thyroid hormones and reproductive characteristics in three breeds of Iranian fat-tailed rams throughout one year. Pak. J. Biotechnol. Sci. 10:3420-3424.

Ernst LK, Dmitriev NG (2007). Sheep: transbalkan finewool. ftp: //ftp.fao.org /docrep/ fao/009/ ah759e/ah 759e16.pdf.

Evans G, Maxwell WMC (1987). Salamon's artificial insemination of sheep and goats. pp. 17-30.

Galal ESE, El-Gamal AA, Aboul-Naga A (1978). Male reproductive characteristics of Merino and Ossimi sheep and their crosses. Anim. Prod. 27:261-267.

Goot $\mathrm{H}$ (1969). Effect of light on spring breeding of mutton Merino ewes. J. Agric. Sci. Camb. 73:177-180.

Gorman MR, Zucker I (1995a). Seasonal adaptations of Siberian hamsters: II. Pattern of change in day length controls annual testicular and body weight rhythms. Biol. Reprod. 53:116-125.

Gundogan M (2007). Seasonal variation in serum testosterone, $T_{3}$ and andrological parameters of two Turkish sheep breeds. Small Rumin. Res. 67:312-316.

Hafez ESE (1952). Studies on the breeding season and reproduction of the ewe. J. Agric. Sci. Camb. 42:189-265.

Ibrahim SA (1997). Seasonal variations in semen quality of local and crossbred rams raised in the United Arab Emirates. Animal Reprod. Sci. 49:161-167.

Janett F, Thun R, Niederer K, Burger D, Hassig M (2003). Seasonal changes in semen quality and freezability in the Warmblood stallion. Theriogenology 60:453-461.

Kafi M, Safdarian M, Hashemi M (2004). Seasonal variation in semen characteristics, scrotal circumference and libido of Persian Karakul rams. Small Rum. Res. 53:133-139.

Karagiannidis A, Varsakeli S, Alexopoulos C, Amarantidis I (2000). Seasonal variation in semen characteristics of Chios and Friesian rams in Greece. Small Rumin. Res. 37:125-130. 
Karagiannidis A, Varsakeli S, Karatzas G (1999). Characteristics and seasonal variations in the semen of Alpine, Saanen and Damascus goat bucks born and raised in Greece. Theriogenology 53:12851293.

Kishk WH (2008). Interrelationship between ram plasma testosterone level and some semen characteristics. Slovak J. Anim. Sci. 41:67-71.

Mandiki SNM, Deriscke G, Bister JL, Paquay R (1998). Influence of season and age on sexual maturation parameters of Texel, Suffolk, and Ile-de- France rams. 1. Testicular size, semen quality and reproductive capacity. Small Rumin. Res. 28:67-79.

Moghaddam GH, Pourseif MM, Asadpour R, Rafat SA, Jafari R (2012). Relationship between levels of peripheral blood testosterone, sexual behavior, scrotal circumference and seminal parameters in crossbred rams. Acta Sci. Veterin. 40:1049.

Robinson JE, Karsch FJ (1987). Photoperiodic history and a changing melatonin pattern can determine the neuroendocrine response of the ewe to daylength. J. Reprod. Fert. 80:159-165.

Robinson JJ (1981). Photoperiodic and nutritional influences on the reproductive performance of ewes in accelerated lambing systems. Pages 1-10 in Proc. 32 ${ }^{\text {nd }}$ Annu. Mtg., of the European Association for Animal Production (EAAP), Zagreb, Croatia.

Rosa HJD, Bryant MJ (2003). Seasonality of reproduction in sheep. Small Rumin. Res. 48:155-171.
Salisbury GW, VanDemark NL, Lodge JR (1978). Physiology of reproductive and artificial insemination of cattle. Second edition. San Francisco, CA: WH freeman and company.

SAS (1996). SAS/STAT software: Changes and Enhances Through Release 6.12. SAS Institute Inc., Cary, NC, USA.

Simplicio AA, Riera GS, Nelson EA, Pant KP (1982). Seasonal variation in seminal and testicular characteristics of Brazilian Somali rams in the hot semi-arid climate of tropical northeast Brazil. J. Reprod. Fert. 66:735-738.

Talebi J, Souria M, Moghaddam A, Karimi I, Mirmahmoodi M (2009). Characteristics and seasonal variation in the semen of Markhoz bucks in western Iran. Small Rumin. Res. 85:18-22.

Zamiri MJ, Khalili B, Jafaroghli M, Farshad A (2010). Seasonal variation in seminal parameters, testicular size, and plasma testosterone concentration in Iranian Moghani rams. Small Rumin. Res. 94:132136.

Zamiri MJ, Khodaei HR (2005). Seasonal thyroidal activity and reproductive characteristics of Iranian fat-tailed rams. Anim. Reprod.. Sci. 88:245-255.

Zarazaga LA, Guzman JL, Domınguez C, Perez MC, Prieto R (2005). Effect of plane of nutrition on seasonality of reproduction in Spanish Payoya goats. Anim. Reprod. Sci. 87:2. 